\title{
EFFECT OF ECONOMIC RECESSION ON DEVELOPMENT EXPENDITURE, DOMESTIC INVESTMENT AND FOREIGN DIRECT INVESTMENTS IN MALAYSIA
}

\author{
AAINAA IZZATI AZMAN, NOR ERMAWATI HUSSAIN*AND JAHARUDIN PADLI
}

\author{
School of Social and Economic Development, Universiti Malaysia Terengganu, Kuala Nerus, Terengganu,
} Malaysia.

*Corresponding author: ermawati@umt.edu.my

\begin{abstract}
Malaysia is also affected by the economic crisis as it applies the door-to-door policy economy even though the crisis has started on a global platform. Therefore, the objective of this study is to see how far economic recession affects development expenditure, domestic investment, and foreign direct investment in Malaysia. Using secondary data from 1980 to 2015, unit root tests, Johansen co-integration test, Vector Error Correction Model (VECM), and Granger-causality test were carried out. The findings showed that there was a long run relationship between the economic recession and at least one independent variable while there was no short run relationship between the variables. For causal relationships, the economic recession was the cause of domestic development and investment expenditure while foreign direct investment was the cause of the recession, domestic development, and investment spending. Hence, the government must ensure economic stability by implementing various policies.
\end{abstract}

Keywords: Economic recession, development, domestic development, investment, expenditure

\section{Introduction}

An open economic system is not a new system, but one that practices an open economic system will receive a major impact including Malaysia. Malaysia is exposed to the risk of an economic recession caused by changes in the international economy (Abdullah \& Yuliyusman, 2010). This condition is associated with financial flows, trade and other activities that require cooperation with foreign countries. Through the open economic system, Malaysia has also been affected by the economic crisis in other countries (Jauhari et al., 2005; Abdullah \& Yuliyusman, 2010).

The Asian financial crisis in 1997 has affected Malaysia's economic situation. According to Khor (2017), Executive Director at the South Center, the crisis began as speculation for Thailand's currency drop by George Soros, an expert in manipulating world finances. This situation has led to instability in the foreign currency exchange rate and thus impacted countries with no strong foreign reserves in the financial markets.

From 14 July 1997 to 7 January 1998, Malaysia was met with economic crisis. The value of Malaysian Ringgit dropped from RM $2.50=$ USD 1 to RM $4.88=$ USD 1. As a result, Gross Domestic Product (GDP) growth in 1998 dropped from $7 \%$ in 1997 to $-7 \%$ in 1998 . This situation led to higher debt (Mahani et al., 2003), and adversely affected foreign investors in that they lost the confidence to continue investing in Malaysia. The foreign investor brought out all the investments to invest in other countries (Shafie, 2017).

Then in mid-2007, there was an interruption in the US financial system, as a result of the subprime asset quality decline (Pajarskas \& Jociene, 2014). This situation led to the collapse of the stock exchange around the world. The Wall Street Stock Exchange continued to fall until the index value was as high as 700 points within a day. As a result, giant companies in the United States faced financial difficulties due to the mortgage crisis (Acharya \& Richardson, 2009; Pajarskas \& Jociene, 2014).

In addition, the economic crisis in 2007 was attributed to the failure of the United States financial institutions globally. The crisis was due to systemic disruptions across global financial markets (Acharya \& Richardson, 2009). This situation affected international trade activities. Most countries dealt in import and export in the trade with the United States. There were many countries that were holding US Treasury bonds. China was holding US Treasury bonds amounting to USD \$ 503.8 billion (Chinadaily.com, 2008). The economic crisis that struck the US caused bond prices to fall. It further undermined China's assets and also had a negative impact on China's trade with Malaysia. This situation led to the freezing of bank and credit markets in most financial centres around the world.

The collapse of the Malaysian Ringgit exchange rate and the drop in crude oil prices in the international market affected Malaysia as it is an oil-exporting country. On December 1, 2014, the FBM KLCI Malaysia Stock Exchange Index fell more than 40 points equivalent to $2.5 \%$, driven by the fall of blue chips, oil and gas counters and Petronas subsidiaries such as Petronas Dagangan Berhad, Petronas Chemical and Petronas Gas (New Straits Time, 2014). As a result, many foreign investors began to pull out their portfolio investments such as stocks, bonds and currencies from Malaysia. 
This monetary economic issue not only affected one country but also affected the stability of the global economy including Malaysia. Hence, this study was conducted to examine the impact of the recession on development, domestic investment and foreign investment in Malaysia. The economic downturn is due to several factors such as inflation, financial flows and interest rates. This recession is seen as a big issue as it affected most economic activities such as the manufacturing, manufacturing and basic services of consumers. This situation caused some firms in the industry to shut down their business operations. As a result, it contributed to the decline in the gross domestic product (GDP) rate. Indirectly, the quality of life of Malaysians was affected. This situation led to unemployment rate in Malaysia rising due to the reduction of staff in the private sector (Economic Development and International Cooperation, 2009).

According to Riyadi and Bratakusumah (2005), development refers to a process of change implemented according to the plan. Planning in development is very important to form a strategy to change the country in a better direction. However, the term of this development may have different meanings but in general, it refers to an effort made to transform a society or nation from a retreat situation to a developed nation. Additionally, it refers to human resource capability to meet their potential to ensure they are able to obtain the desired basic needs. To meet this requirement, a country needs investment injection aimed at achieving national development.

Malaysia is a country that has long been introduced to this foreign direct investment (FDI) system and it has been practiced since the British colonial era (Yusof, 2011). FDI is linked to international capital transfers such as human capital and financial capital (Froot, 1993). FDI has provided many benefits to Malaysia, including improving the country's revenue, production volume, and national income through import and tax systems. In addition, FDI can open job opportunities to locals in Malaysia, promoting technology transfer processes and skills for large-scale industries from abroad. At the same time, FDI can help increase the per capita income of Malaysians.

Thus, FDI is seen to be a key driver of domestic capital flows for Malaysia, known as domestic investment in the country. Hence, Malaysia's economic growth is highly dependent on the influx of FDI and will further stimulate development growth in Malaysia. If the FDI inflows are diminished, the Malaysian economy will experience a recession and thus will affect the country's development. As shown in Figure 1, Malaysia's GDP in 2010 was RM 821,434 million. Then, it increased by RM 90,299 million to RM 911,733 million in 2011. In 2012, Malaysia's GDP rose to RM 971,253 million and subsequently increased to reach RM 1,157,139 million in 2015 (Department of Statistics Malaysia, 2017).

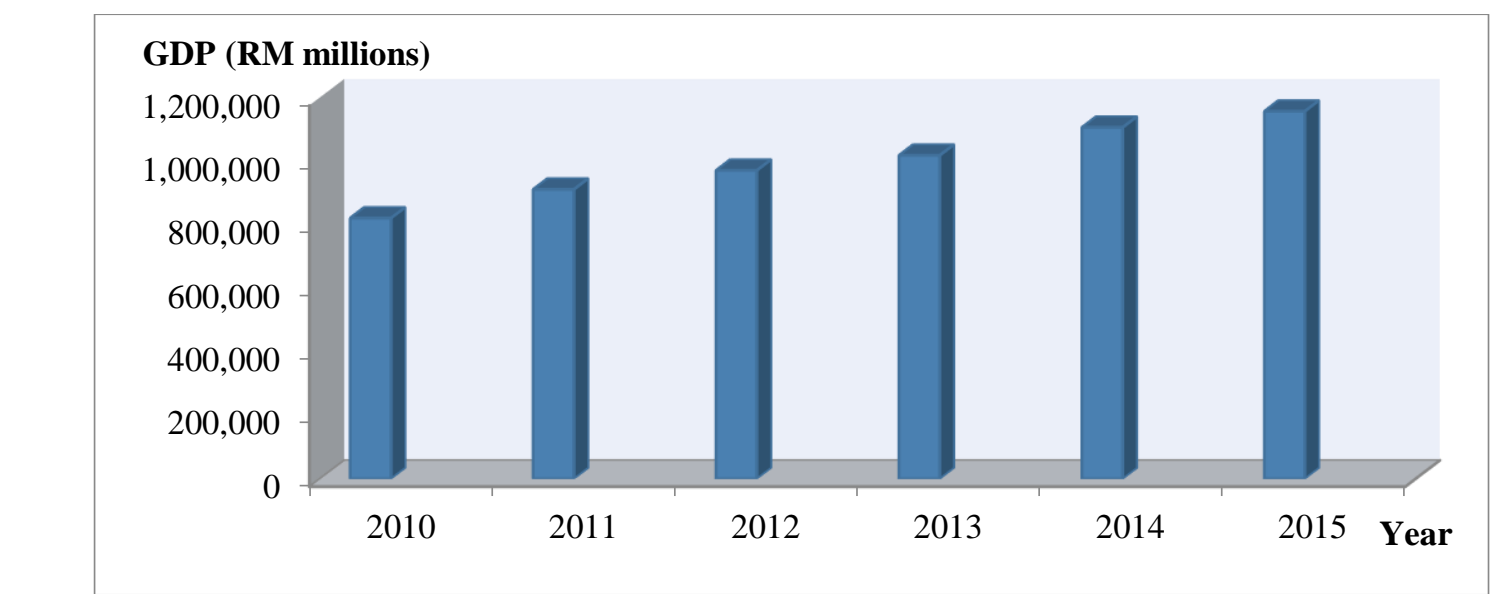

Source: Department of Statistic, Malaysia (2017)

Figure 1: Gross Domestic Product (GDP) Year 2010 to 2015

\section{Literature Review}

There are several studies on the relationship between economic growth and government spending (Asri et al., 2010; Dzubaidi et al., 2013; Hasnul, 2015). Using the Johansen co-integration and VECM method, Asri et al. (2010) found that Malaysia's economic growth was influenced by government spending in the short and long run. Meanwhile, using the Two-Stages Least Squares (2SLS) method, Dzubaidi et al. (2013) found a positive relationship between government spending and economic growth in Malaysia. In Malaysia, the results of the study conducted by Hasnul (2015) showed that there was a negative relationship between government expenditure and economic growth.

Furthermore, there are some recent studies on the relationship between economic growth and domestic investment and foreign investment (Shawa et al., 2014; Tang et al., 2008). In Kenya, Shawa et al. (2014) found that there was a long run relationship between economic growth and foreign investment and domestic investment. 
For causal relationships, Shawa et al. (2014) found bilateral ties between economic growth and domestic investment. In China, the results of the study conducted by Tang et al. (2008) showed that there was a bilateral relation between domestic investment and economic growth.

In addition, there are some studies on the relationship between foreign direct investment and economic growth (Baharumshah \& Almasaied, 2009; Ekanayake \& Ledgerwood, 2010; Karim et al., 2013; Melnyk et al., 2014; Upreti, 2015; Nor et al., 2015; Mahadika et al., 2017). In Malaysia, Baharumshah and Almasaied (2009) found that foreign direct investment had a positive relationship with economic growth. A study conducted by Ekanayake and Ledgerwood (2010) on 85 developing countries from 1980 to 2007 found that foreign direct investment had a positive impact on economic growth in developing countries. Similar to the study conducted by Ekanayake and Legdgerwood (2010) studies, Karim et al. (2013) also found a positive relationship between economic growth and foreign direct investment in 14 MENA countries.

Besides that, Melnyk et al. (2014) saw the impact of Foreign Direct Investment on economic growth in 26 countries with emerging economies and those undergoing economic transitions from European central states, the Commonwealth independence (CIS) and the Baltic countries from 1980 to 2010 . The study found that foreign direct investment had a significant relationship with economic growth in the home countries. Meanwhile, Upreti (2015) studied the relationship

$$
\mathrm{GDP}=\beta_{0}+\beta_{1} \mathrm{PP}_{\mathrm{t}}+\beta_{2} \mathrm{PD}_{\mathrm{t}}+\beta_{3} \mathrm{PLA}_{\mathrm{t}}+\varepsilon_{\mathrm{t}}
$$

where GDP is economic recession, DE is development expenditure, DI is domestic investment, FDI is foreign direct investment, $\varepsilon$ is error and $t$ is year. There were several tests conducted in this study, including unit root tests, Johansen co-integration, Vector Error Correction Model (VECM) and Granger-causality test. Unit root test was conducted to test the stationary of all variables. Hence, all variables were tested at each level and the first differentiation was performed using the Augmented Dickey-Fuller (ADF) and Phillip Perron (PP) Test. The equation is as below:

$$
\Delta \lambda_{1}=\alpha_{1}+\alpha_{2}+\phi \lambda_{\mathrm{t}-1}+\beta_{\mathrm{i}} \Sigma_{i=1}^{m} \Delta \lambda \mathrm{X}_{\mathrm{t}-\mathrm{i}}+\varepsilon_{\mathrm{t}}
$$

where $\lambda$ refers to the main variables studied, $\Delta$ is the time trend, $\mathrm{t}$ is the time trend, and $\varepsilon$ is the error. The terms used here such as $\alpha 1, \alpha 2, \beta 1$, and ... $\beta \mathrm{m}$ are a set of parameters to estimate. If the stationary test is important then the variable is stationary and does not have a unit root test. Therefore, the null hypothesis will be rejected and the alternative hypothesis will be accepted. However, if the stationary test is not important, the variable is not stationary and has a unit root test. Therefore, the null hypothesis will be accepted. The between foreign investment and economic growth in 67 developing countries using data from 1995, 2000, 2005 and 2010. Using the Ordinary Least Squares (OLS) test, the findings showed that higher investment rates led to higher positive impact on economic growth in these developing countries.

Next, Nor et al. (2015) looked at the relationship between foreign direct investment and economic growth in 30 developed and developing countries from 1999 to 2009. The findings showed that countries with high level of stock market development and high efficiency would receive many benefits from direct investment foreign. However, foreign direct investment inflows had a negative correlation with economic growth in these countries. This is because higher inflows of foreign investment could cause slow economic growth. While in Indonesia, using time series data from 1981 to 2013, Mahadika et al. (2017) found that there was a long run relationship between economic growth and foreign direct investment.

\section{Methodology}

To meet the objective of the study, which was to investigate the effect of economic recession on development expenditure, domestic investment, and foreign direct investment in Malaysia, several econometric approaches were used. Using Malaysia's time series data from 1980 to 2015, the equation (1) was formed:

hypothesis for this study is:

$$
\begin{array}{r}
H_{0}: \phi \neq 0(\phi \text { not stationary }) \\
\left.H_{1}: \phi=0 \text { ( } \phi \text { stationary }\right)
\end{array}
$$

The Johansen co-integration test was used in this study to examine the long run relationship between all variables. The VAR levels, with $\mathrm{Xt}$ defined as GDP, Development Expenditure, Domestic Investment and Foreign Direct Investment were as follows:

$\mathrm{X}_{\mathrm{t}}=\mathrm{c}+\sum_{j=1}^{p} \Gamma_{\mathrm{j}} \Delta \mathrm{X}_{\mathrm{t}-\mathrm{j}}+\varepsilon_{\mathrm{j}}$

If the variable in Xt is I (1), the VAR in Eq. (5) is not stationary. If there is no joint co-integration, statistical conclusions are not possible by using regular tests. In view of this situation, the difference in the series must be determined and the first difference, the VAR should be estimated as follows:

$\Delta \mathrm{X}_{\mathrm{t}}=\mathrm{c}+\sum_{j=1}^{p} \Gamma_{\mathrm{j}} \Delta \mathrm{X}_{\mathrm{t}-\mathrm{j}}+\varepsilon_{\mathrm{t}}$

The co-integration vector poses a stationary variable. If this is the case, the VAR in Eq. (6) may be written as: 
$\mathrm{X}_{\mathrm{t}}=\mathrm{c}+\Sigma_{j=1}^{p} \Gamma_{\mathrm{j}} \Delta \mathrm{X}_{\mathrm{t}-\mathrm{j}}+\Pi \mathrm{X}_{\mathrm{t}-1}+\varepsilon_{\mathrm{t}}$

In Eq. (7), $\Pi$ is the rational matrix which can be divided into:

$$
\Pi=\alpha \beta^{!}
$$

where $\alpha$ is the matrix of $3 \times \mathrm{r}$ and $\beta$ is the $3 \times \mathrm{r}$ cointegrating vector, $r$ is the number of vectors integrating together. Following the Johansen procedure (Ighodaro, 2010), the number of joint integration vectors was tested using integrated VAR together as in Eq. (7). Subsequently, the test of the error correction vector model (VECM) was conducted to see short run relationships and long run error correction. In general, there are two variable systems, $\mathrm{F}$ and $\mathrm{K}$, and the cointegration equation as:

$$
\mathrm{F}_{\mathrm{t}}=\beta \mathrm{K}_{\mathrm{t}}
$$

Hence, the VECM model that can be formed from Equation (9) above is:

$$
\begin{aligned}
& \Delta \mathrm{F}_{\mathrm{t}}=\alpha_{1}\left(\mathrm{~K}_{\mathrm{t}-1}-\beta \mathrm{F}_{\mathrm{t}-1}\right)+\varepsilon_{1}, \mathrm{t} \\
& \Delta \mathrm{K}_{\mathrm{t}}=\alpha_{2}\left(\mathrm{~K}_{\mathrm{t}-1}-\beta \mathrm{F}_{\mathrm{t}-1}\right)+\varepsilon_{2}, \mathrm{t}
\end{aligned}
$$

\section{Results and Discussion}

Table 1 and Table 2 show the results of unit root tests for Augmented Dickey Fuller and Phillip Perron. There were 2 unit root test conditions carried out that were constant and trend. At constant, all variables were not significant at levels. However, in the first difference, all variables
In equations (10) and (11), the right part of the equation is an error correction. In the long run, this error is zero value. However, if $\mathrm{F}$ and $\mathrm{K}$ deviate from long run relationships, these correction errors will not be worth zero, and each variable is coordinated to maintain longrun balance relationships. The coefficient of $\alpha \mathrm{i}$ coefficients measures the adjustment speed of the endogenous to i variable to return to longrun balance. Next, Granger-Causality test is used to study causal relationships between two variables. If the p-value of the variable $\mathrm{Y}$ is significant to predict the value of the variable $X$, then $Y$ has a causal relationship with $X$ and vice versa. This test is based on the equation below:

$$
\begin{aligned}
& \mathrm{Y}_{\mathrm{i}}=\gamma_{0}+\sum_{z=1}^{p} \gamma_{\mathrm{z}} \mathrm{Y}_{\mathrm{t}-\mathrm{z}}+\sum_{i=1}^{q} \lambda_{\mathrm{i}} \mathrm{X}_{\mathrm{t}-1}+\mu_{\mathrm{t}} \\
& \mathrm{X}_{\mathrm{i}}=\varphi_{0}+\sum_{z=1}^{p} \delta_{\mathrm{z}} \mathrm{X}_{\mathrm{t}-\mathrm{z}}+\sum_{i=1}^{q} \Psi_{\mathrm{i}} \mathrm{Y}_{\mathrm{t}-\mathrm{i}}+\varepsilon_{\mathrm{t}}
\end{aligned}
$$

where $\mathrm{Y}$ and $\mathrm{X}$ are the tested variables, $\mu$ and $\varepsilon$ refer to the error, and $t$ is the length of time while $\mathrm{z}$ and $\mathrm{i}$ are the lag numbers. The null hypothesis is $\lambda \mathrm{i}=\Psi \mathrm{i}=0$ for all $\mathrm{i}$. In the alternative hypothesis that $\lambda i \neq 0$ and $\Psi i \neq 0$ for at least some $\mathrm{i}$ if the $\lambda \mathrm{i}$ coefficient is important but $\Psi \mathrm{i}$ is not significant, then $\mathrm{X}$ is the cause of $\mathrm{Y}$. However, if both coefficients are important, then the effects of constant causal occurs both ways.

were significant at the $1 \%$ significance level. In the case of the trend, all the variables were not significant at the level. However, in the first difference, all variables were significant at the $1 \%$ significance level. Hence, the null hypothesis was rejected and the alternative hypothesis was accepted. Subsequently, testing for long run relationships, short run relationships and causality tests would continue.

Table 1: Augmented Dickey-Fuller (ADF) Unit Root Test

\begin{tabular}{lcccc}
\hline \multirow{2}{*}{ Variables } & \multicolumn{2}{c}{ Constant } & \multicolumn{2}{c}{ Constant \& Trend } \\
\cline { 2 - 4 } & -0.4386 & $-5.9845^{* * *}$ & -2.2014 & First Difference \\
\cline { 2 - 4 } & $(0.8914)$ & $(0.0000)$ & $(0.4741)$ & $-5.9036 * * *$ \\
DE & -0.5608 & $-4.9751 * * *$ & -2.9883 & $-4.9003 * * *$ \\
& $(0.8664)$ & $(0.0003)$ & $(0.1500)$ & $(0.0020)$ \\
DI & -2.0550 & $-7.9017 * * *$ & $-4.1415 * *$ & $-7.7611 * * *$ \\
& $(0.2632)$ & $(0.0000)$ & $(0.0128)$ & $(0.0000)$ \\
FDI & -2.0136 & $-6.5494 * * *$ & -2.1080 & $-6.5966 * * *$ \\
& $(0.2799)$ & $(0.0000)$ & $(0.5236)$ & $(0.0000)$ \\
\hline Notes: () refer to probability $* * *, * *$ and $*$ refer to the significant level at $1 \%, 5 \%$ and $10 \%$.
\end{tabular}


Table 2: Phillip Perron (PP) Unit Root Test

\begin{tabular}{lcccc}
\hline Variables & \multicolumn{2}{c}{ Constant } & \multicolumn{2}{c}{ Constant \& Trend } \\
\cline { 2 - 5 } GDP & Level & First Difference & Level & First Difference \\
\hline & -0.5638 & $-3.9025 * * *$ & -2.3495 & $-5.6749 * * *$ \\
DE & $(0.8647)$ & $(0.0057)$ & $(0.3972)$ & $(0.0003)$ \\
& -0.3062 & $-3.8878 * * *$ & -2.9141 & $-5.4589 * * *$ \\
DI & $(0.9129)$ & $(0.0059)$ & $(0.1724)$ & $(0.0006)$ \\
& -2.3440 & $-4.9043 * * *$ & -3.1993 & $-4.5336 * * *$ \\
& $(0.1654)$ & $(0.0004)$ & $(0.1031)$ & $(0.0057)$ \\
FDI & -2.2987 & $-3.8452 * * *$ & $-2.7361[1]$ & $-6.4476 * * *$ \\
& $(0.1787)$ & $(0.0065)$ & $(0.2301)$ & $(0.0000)$ \\
\hline
\end{tabular}

Notes: ( ) refer to probability, $* * *, * *$ and $*$ refer to the significant level at $1 \%, 5 \%$ and $10 \%$.

Next, the Johansen Co-integration test was conducted to identify the existence of long run relationship between variables. Table 3 shows the Johansen co-integration test results. The results showed that the value of hypothesis $r=0$ was significant at $5 \%$ significance level for trace test and maximum eigenvalue. Hence, there was a long run relationship between economic ties with at least one variable (development expenditure, domestic investment, and foreign direct investment).

Table 3: Johansen Co-integration

\begin{tabular}{|c|c|c|c|c|}
\hline \multirow[t]{2}{*}{ Hypothesis } & \multicolumn{2}{|c|}{ Trace } & \multicolumn{2}{|c|}{ Maximum Eigenvalue } \\
\hline & Trace Statistic & Probability & Max-Eigen Statistic & Probability \\
\hline $\mathrm{r}=0 *$ & 51.1502 & 0.0237 & 30.6864 & 0.0193 \\
\hline$r>1$ & 20.4638 & 0.3919 & 12.7042 & 0.4798 \\
\hline$r>2$ & 7.7597 & 0.4915 & 5.8333 & 0.6347 \\
\hline
\end{tabular}

Table 4 shows the results of the Vector Correction Vector Model (VECM) Test. The results showed that there was no correction error in the long run because of the ECM value of -0.0048 that was not significant. Furthermore, for short run relationships, the findings showed that all variables were not significant. Hence, there was no short run relationship between economic recession and development expenditure, domestic investment, foreign direct investment. Thus, the null hypothesis was accepted and the alternative hypothesis was rejected.

\begin{tabular}{ccc}
\multicolumn{2}{c}{ Table 4: Vector Error Correction Model (VECM) Test } \\
\hline Variables & Coefficient & Probability \\
ECM & -0.0048 & 0.9330 \\
DE & 0.0809 & 0.2723 \\
DI & -0.0287 & 0.3564 \\
FDI & -0.0044 & 0.8878 \\
C & $0.0841 * * *$ & 0.0004 \\
\hline Note: $* * *$ refers to the significant level at $1 \%$.
\end{tabular}


Table 5 shows the findings for granger-causality tests. The results showed that economic recession was the cause for development expenditure (significant at the $1 \%$ ) and domestic investment (significant at the 5\%). Meanwhile, foreign direct investment was the cause of economic recession and significant at $10 \%$ significance while foreign direct investment was the cause of development expenditure (significant at the 5\%) and domestic investment (significant at the 10\%).

Table 5: Granger-causality Test

\begin{tabular}{ccc}
\hline Hypothesis Null & F-Statistic & Probability \\
\hline DE $\rightarrow$ GDP & 0.6266 & 0.5415 \\
GDP $\rightarrow$ DE & $6.9728 * * *$ & 0.0034 \\
\hline FDI $\rightarrow$ GDP & $2.5168^{*}$ & 0.0982 \\
GDP $\rightarrow$ FDI & 0.2460 & 0.7835 \\
\hline DI $\rightarrow$ GDP & 0.5853 & 0.5634 \\
GDP $\rightarrow$ DI & $5.1421 * *$ & 0.0123 \\
\hline FDI $\rightarrow$ DE & $3.8887 * *$ & 0.0319 \\
DE $\rightarrow$ FDI & 0.2139 & 0.8087 \\
\hline DI $\rightarrow$ DE & 1.3702 & 0.2700 \\
DE $\rightarrow$ DI & 0.8525 & 0.4368 \\
\hline DI $\rightarrow$ FDI & 0.2556 & 0.7762 \\
FDI $\rightarrow$ DI & $2.8202 *$ & 0.0760 \\
\hline
\end{tabular}

Notes: $\rightarrow$ refer to 'does not granger cause', $* * *, * *$ and $*$ refer to significant level at $1 \%, 5 \%$ and $10 \%$.

Based on the results as shown in Table 3 and Table 4 , there was a long run relationship between economic recession with at least one independent variable while there was no short run relationship between the variables. Thus, based on the causal relationship test as shown in Table 5, Figure 2 was formed. Figure 2 shows the relationship between all variables in the long run. In the long run, the recession would be the cause of development expenditure and significant at the $1 \%$ level of significance. In addition, economic recession variables would also be a cause for domestic investment in the long run and significant at the 5\% significance level. Meanwhile, foreign direct investment was seen as a cause for Malaysia's long run recession and was significant at $10 \%$ level. There was also an indirect relationship between the variables of foreign direct investment and domestic investment and development expenditure. Foreign direct investment was seen as a cause for the long run and significant development expenditure at the 5\% significance level. While foreign investment was seen as a cause for domestic investment in the long run and significant at $10 \%$ level of significance. 


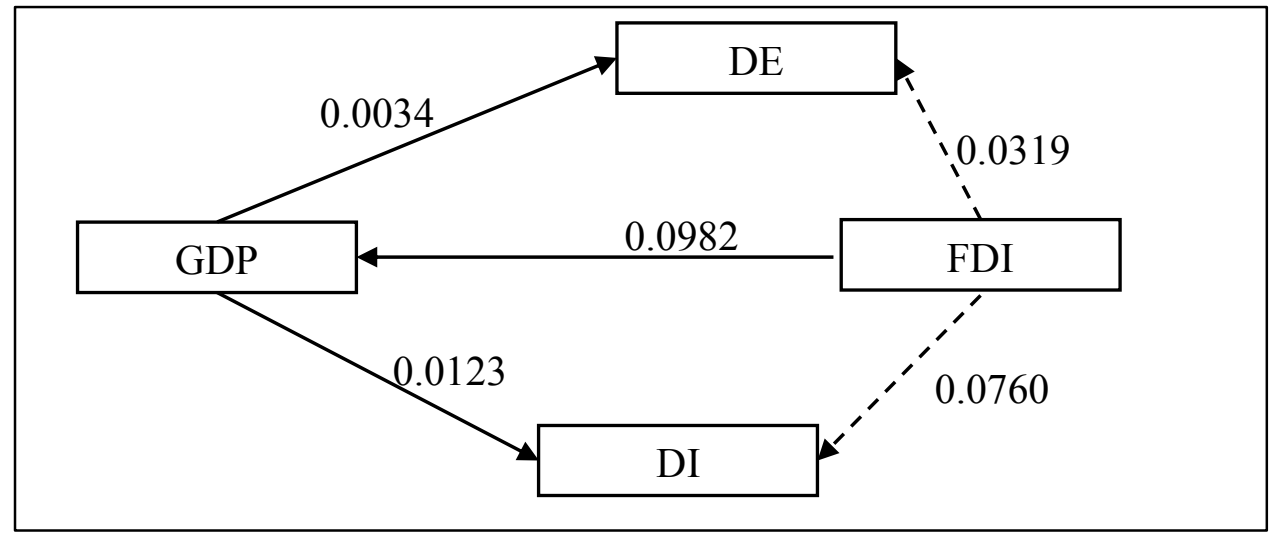

Note: $\longrightarrow$ refer to direct relationship while

$-\rightarrow$ refer to indirect relationship.

Figure 2: Long Run Effect and Granger Causality.

Based on the results, it can be suggested that the economic recession has only long run impact on development expenditure and domestic investment. Meanwhile, foreign direct investment is the cause of economic recession. Foreign direct investment also has an indirect impact on development expenditure and domestic investment. Hence, foreign direct investment is important to promote Malaysia's economic growth in the long run. But in the short run, all variables do not affect economic recession.

\section{Conclusion}

Using the time series data from 1980 to 2015, the objective of the study, which is to see how far the impact of the economic recession affects development expenditure, domestic investment and foreign direct investment in Malaysia, was achieved. Unit root tests indicated that all variables were insignificant on the state of the constant and trend conditions while significant in the first differentials. Furthermore, the findings suggested that there was a long run relationship between economic growth and at least one variable while there

\section{References}

Abdullah, H. \& Yuliyusman, F. (2010). Kesan Kebebasan Ekonomi Terhadap Pertumbuhan Ekonomi Negara: Kajian Empirikal di ASEAN-5. Journal of Governance \& Development. vol. 6, 1-13.

Acharya, V. V. \& Richardson, M. (2009). Causes of the Financial Crisis. Critical Review: A Journal of Politics and Society, vol. 21, 195-210.

Arsyad, Lincolin. (2010). Ekonomi Pembangunan. Yogyakarta; STIM YKPN.

Asri, N. M., Tahir, M. Z. M., \& Endut, W. (2010). Komposisi Perbelanjaan Kerajaan dan Pertumbuhan Ekonomi: Kajian Empirikal di Malaysia. Jurnal Kemanusiaan, 23-45. was no short run relationship between economic growth and other variables. For causal relationships, the study found that economic growth was a cause for government development and domestic investment while foreign investment was seen as a cause for economic growth, domestic investment and development expenditure.

In order to strengthen Malaysia's economic growth, policymakers must find ways to attract foreign investors to invest in Malaysia in various sectors such as manufacturing, real estate, insurance and hire purchase. This is because foreign investment factors are seen as a cause for Malaysia's long run economic growth. The inclusion of foreign investment will indirectly create more employment opportunities for Malaysians and thus become a capital injection to the Malaysian government for national development and can convince local investors to continue investing in their own country. Thus, policymakers need to strengthen cooperation networks with regional countries to attract more foreign investors into Malaysia.

Baharumshah, A. Z. \& Almasaied, S. W. (2009). Foreign Direct Investment and Economic Growth in Malaysia: Interactions with Human Capital and Financial Deepening. Emerging Markets Finance \& Trade. Vol. 45 (1), 90-102.

Dzubaidi, R. A. M., Ismail, R., \& Sarmidi, T. (2013). Peranan Perbelanjaan Kerajaan Terhadap Pembangunan Manusia dan Pertumbuhan Ekonomi. Prosiding Perkem VIII, Jilid 2, 872 - 879

Ekanayake, E. M., \& Ledgerwood, J. R. (2010). How Does Foreign Direct Investment Affect Growth In Developing Countries? An Empirical Investigation. The International Journal of Business and Finance Research Vol. 4, No. 3, 43-53. 
Froot, K. A. (1993). Foreign Direct Investment. Chicago: National Bureau of Economic Research, University of Chicago Press

Hasnul, A. G. (2015). The Effects of Government Expenditure on Economic Growth: The Case of Malaysia. MPRA Paper No. 71254.

Jauhari, A., Said, F. F. \& Tahir, M. Z. M. (2005).Kemeruapan Kadar Syarat Perdagangan dan Pertumbuhan: Peranan Perbelanjaan Fiskal. International Journal of Management Studies. Vol. 12 (2). 125-144.

Karim, Z. A., Ren, C. C., \& Yaacop, M. (2013). Kualiti Institusi, Makroekonomi dan Pelaburan Langsung Asing (PLA): Kajian Data Panel di Negara MENA. Asian Journal of Accounting and Governance 4, 61-71

Khor, M. (2017). The Asian Financial Crisis - 20 Years Later. The Star online. From https://www.thestar.com.my/opinion/columnists/glo bal-trends/2017/07/03/the-asian- financial-crisis20-years-later-it-is-useful-to-reflect-on-whetherlessons-have-been-clear/

Laman Web Rasmi Unit Perancang Ekonomi, Jabatan Perdana Menteri. Keluaran Dalam Negara Kasar (KDNK). Rerieved on 5 November 05, 2017 from http://www.epu.gov.my/ms/statistikekonomi/akaun-negara

Laman Web Rasmi Unit Perancang Ekonomi, Jabatan Perdana Menteri. Perbelanjaan Pembangunan. Diakses pada November 05, 2017 dari http://www.epu.gov.my/ms/statistikekonomi/sektor-awam

Laman Web Rasmi Unit Perancang Ekonomi, Jabatan Perdana Menteri. Projek Kelulusan MIDA mengikut Negeri. Rerieved on 5 November 05, 2017 from http://www.epu.gov.my/ms/statistikekonomi/petunjuk-ekonomi

Mahadika, I., N., Kalayci, S., \& Altun, N. (2017). Relationship between GDP, Foreign Direct Investment and Export Volume: Evidence from Indonesia. International Journal of Trade, Economics and Finance, Vol. 8, No. 1, 51-54

Mahani, Z. A., Shin, K, \& Wang, Y. (2003). Macroeconomic Adjustmenyd and the Real Economi in Korea and Malaysia since 1997. Management of Volatility, Financial Liberalization and Growth in Emerging Economies. Santiago, April 24-25, 2003.

Melnyk, L., Kubatko, O., \& Pysarenko, S. (2014). The Impact of Foreign Direct Investment on Economic
Growth: Case of Post Communism Transition Economies. Problems and Perspectives in Management (Open-Access), 12(1).

Nain, A. S. M., \& Yusoff, R. M., (2003). Konsep, Teori, Dimensi, \& Isu Pembangunan, Universiti Teknologi Malaysia, Skudai, Johor Darul Ta’zim.

Nor, N. H. M., Wah L. S., \& Nor, A. H. S. M. (2015). Pelaburan Langsung Asing, Pertumbuhan Ekonomi dan Kualiti Pembangunan Pasaran Saham. Jurnal Ekonomi Malaysia. Vol. 49 (1), 49-60

Pajarskas, V. \& Jociene, A. (2014). Subprime Mortage Crisis in the United States in 2007-2008: Causes and Consequences (Part 1). Ekonomika. Vol. 93 (4), 85 118.

Sukirno, Sadono. 2007. Makro Ekonomi Modern. Jakarta: PT. Raja Grafindo Persada, 256-257

Shaari, M. S., Hussain, N. E., \& Ismail, M. S. (2012). Relationship between Energy Consumption and Economic Growth: Empirical Evidence for Malaysia. Business System Review. Vol. 2 (1), 17-28.

Shafie, R. (2017). Mengimbau Krisis Kewangan Asia 1997. Utusan Malaysia. Rerieved on 5 November 2017 from http://www.utusan.com.my/rencana/utama/mengim $\underline{\text { bau-krisis }}$ kewangan-asia-19971.501605

Shawa, M. J., Amoro, G., \& Yaoshen. (2014). The Causal Link between Foreign Direct Investment, GDP Growth, Domestic Investment and Export for Kenya: The New Evidence. Journal of Economics and Sustainable Development. Vol.5, No.16, 107-114

Suryawati, D., \& Helpiastuti, S. (2016). Consistency and Reconciliation Model in Regional Development Planning. JEJAK: Jurnal Ekonomi Dan Kebijakan, vol. 9 (2), 241-261.

Tang, S., Selvanathan, E. A., \& Selvanathan, S. (2008). Foreign Direct Investment, Domestic Investment, and Economic Growth in China. Research Paper No. 19, 1-17.

New Straits Times. (2014). FBM KLCI likely to stay on weak note next week. Rerieved on 18 November 2017, from http://www.nst.com.my/news/2015/09/fbmklcilikely-stay weak-note-next-week? $\mathrm{m}=1$

Toodia.my. (2017). Bagaimana Krisis Kewangan Asia 1997 Berlaku?, Rerieved on 18 November 2017, dari 
http://www.toodia.my/2017/08/08/bagaimana

krisis-kewangan asia-1997-berlaku/.

Upreti, P. (2015). Factors Affecting Economic Growth in Developing Countries. Major Themes

in

Economics, 37-54
Yusof, N., (2011). Pelaburan Langsung Asing dan Pembangunan Industri Barangan Elektrik dan Elektronik di Negeri Pulau Pinang, Kemanusiaan Vol. 18, No. 2, (2011) 43-74. 